\title{
Terrorism and the proportionality of Internet surveillance
}

\author{
Ian Brown and Douwe Korff
}

\begin{abstract}
As the Internet has become a mainstream communications mechanism, law enforcement and intelligence agencies have developed new surveillance capabilities and been given new legal powers to monitor its users. These capabilities have been particularly targeted toward terrorism suspects and organisations, which have been observed to use the Internet for communication, propaganda, research, planning, publicity, fundraising and creating a distributed sense of community. Policing has become increasingly pre-emptive, with a range of activities criminalised as "supporting" or "apologising for" terrorism. The privacy and nondiscrimination rights that are core to the European legal framework are being challenged by the increased surveillance and profiling of terrorism suspects. We argue that their disproportionate nature is problematic for democracy and the rule of law, and will lead to practical difficulties for cross-border cooperation between law enforcement agencies.
\end{abstract}

\section{Introduction}

Over the last 15 years the Internet has developed from a specialist network of academic researchers into a mainstream communications mechanism. Around $60 \%$ of the UK population are now regular Internet users, most commonly for e-mail and web browsing (Dutton and Helsper 2007).

As might be expected of any such widespread technology, law enforcement agencies have paid increasing attention to the use of the Internet for criminal purposes, especially by terrorism suspects. Terrorist groups such as Hezbollah have been observed to use the Internet for communication, propaganda, research, planning, publicity, fundraising and creating a distributed sense of community. E-mail and web discussion forums have been used to plan operations, while websites are commonly used to bypass media editorial controls and communicate directly with groups' supporters and potential recruits (Bird 2006; Labi 2006).

In response to this activity policing and intelligence agencies have developed new capabilities and successfully lobbied for new legal powers to put Internet users under surveillance. These have included requirements for Internet Service Providers to facilitate wiretaps and to store information about their customers' communications and Web browsing activities (Brown and Korff 2004; Schjolberg 2007). However, these new powers have caused significant concern that the private lives of Internet users with no connection to terrorism or serious crime are being disproportionately invaded, and are one reason that UK Information Commissioner Richard Thomas believes we are "sleepwalking into a surveillance society" (Ford 2004).

The right to privacy relates to the right to respect for private life, guaranteed by Article 8 of the European Convention on Human Rights, but is also shorthand for a more specific right, usually referred to in terms of "data protection." This is increasingly recognised as a right sui generis (e.g., in Article 8 of the EU Charter on Fundamental Rights) and is not only concerned with protecting individuals from intrusions into their privacy or private life, but more broadly against the improper collecting, storing, sharing and use of their data. It addresses the central issue in the "information society" of the extent of control by "data controllers" over individuals - tellingly referred to as "data subjects" - through possession of their data. 
The proportionality of Internet surveillance touches on fundamental values of a democratic society, raising serious constitutional questions in many states. However, it relates to a phenomenon - terrorism - in response to which states feel obliged to take the most drastic action, if needs be in derogation of their usual human rights obligations applicable in "ordinary" times. Yet terrorism (however defined) is not a passing phenomenon. While wars or other public emergencies generally have a more-or-less clear end (even if this can be muchdelayed), there is no end in sight in the fight against terrorism. Even at the national level, anti-terrorism legislation tends to become semi-permanent (Walker and Akdeniz 2003).

\section{Terrorist use of the Internet}

While much media attention has focussed on the possibilities of dramatic "cyber-terrorism" and even digital "Pearl Harbours," the reality of terrorist use of the Internet is more prosaic (Brown 2007). Researchers have found that online terrorist activity is most commonly for the purposes of communication, propaganda, research, planning, publicity, fundraising and creating a distributed sense of community (Bird 2006).

Terrorists communicate online for the purposes of bonding, social interaction, planning and executing acts. E-mail is their main tool but Voice over IP is also used, both largely to support existing relationships. Blogs, chatrooms and message boards (sometimes password protected) are also used to reach a wider audience, particularly potential supporters and recruits (Ryan 2007). The use of encryption to scramble the contents of messages is no more prevalent amongst terrorists than the general population - not least because it might make messages stand out. The use of steganography to disguise the existence of messages is discussed more by intelligence services than used by terrorists because it is technically challenging and hence less appealing (Bird 2006).

Websites contain varying quality but valuable technical information like maps, plans, how to construct suicide belts or extract toxins, conspiracy theories, militant texts, Qu'ranic interpretations and detailed anti-terrorist programmes. The majority of "recipes" for chemical and biological weapons available online are of poor quality and are unlikely to lead to the production of usable weapons (Stenersen 2007). However, the US Army recently had to remind soldiers of the operational security issues inherent in blogging from the front-line (US Army 2005); one prominent online terrorist wrote in 2004: "I'm looking for soldier footages from within U.S. bases etc" (Labi 2006).

Terrorist websites make strong efforts to increase public sympathy for their cause and sow doubts about the validity of the status quo. The Internet is an ideal propaganda tool and most extremist groups therefore have a Web presence. Sites are cheap to produce while looking professional, adding validity and legitimacy to a cause. It is relatively easy for extremists to use multimedia, which appeals to the young and less literate. To get press coverage groups previously had to attract the attention of journalists and even then could be pushed out by a competing story or editor. Groups can now bypass these gatekeepers and communicate directly with supporters and potential recruits. Al-Qaeda publishes pictures of attacks and lists of "martyrs," and has a seamless public relations effort with its own media agency. Sites are monitored by journalists, who replay the most shocking footage in the mainstream media including videos such as the beheading of American businessman Nicholas Berg. Sites are also a route for disinformation and psychological operations such as casualty figures and attack warnings (Bird 2006). Earlier terrorist groups like ETA and the IRA relied instead on word of mouth and local newspapers.

Terrorist groups monitor online forums for potential new recruits ("armchair jihadis"), who will be contacted directly by an ideologue (an "international dating service") who will 
radicalise and train the recruit. Once fully prepared they are passed on to an operational leader, who will provide tactical training such as countersurveillance, target selection or bombmaking. The armchair jihadi can now form a cell offline, and further support will come on the ground (Shahar 2007).

Websites and forums are also used to give terrorists and their supporters a sense of belonging (Labi 2006). Sites reassure members they are not misfits or loners. Sites have their own iconography - horses, flags and sunrises are the online equivalents of scarves. Hezbollah and Hamas produce souvenirs featuring logos. While local terrorist motivations (e.g. in Chechnya, Afghanistan, Saudi Arabia) are very different, their websites give them a global jihad spin. The youngest, least educated and literate (especially religious converts) are particularly strongly influenced by multimedia propaganda (Bird 2006). The Internet is providing a social networking function for terrorists, normalising their behaviour and helping to develop their sense of persecution.

The Internet has also changed the way global terrorism functions. Groups can now be more geographically dispersed and non-hierarchical. Such networks have been proven capable of defeating much more powerful hierarchies. "Leaderless resistance," which originated in printed media, can now work much more effectively. Terrorist organisations can flourish without state sponsors, who are vulnerable to threats of retaliation. They are instead sponsored by sub-state entities that operate more like corporations (Shahar 2007).

Terrorist use of new technologies provides new opportunities for intelligence gathering and disruption of operations by intelligence agencies. They can use active and passive attacks (using viruses and surveillance/traffic analysis) on terrorist computers to gather address books, cookies, passwords and similar information. Counter-terrorist operations include the use of black propaganda to destroy trust. If agencies can identify and take out purveyors of good technical information, they can flood channels with misinformation and leave the less informed to propagate bad information. At the same time they gather intelligence on participants, organisations and their modus operandi. Most ideological debate takes place on open recognised sites, including from senior participants, which allows up-and-coming leaders to be identified (Shahar 2007).

Jihadi websites provide much information about their organisations, including core beliefs; ideological divisions; ultimate goals and overall game plan; methods proposed to reach these goals; and who makes decisions and how? They often detail ideological splits and identify clerics who will dispute Qu'ranic interpretations who can be co-opted, intimidated or killed, providing a mechanism for intelligence agencies to challenge terror groups' legitimacy and siphon off recruits. Movements often split over theological (not tactical) disagreements.

Tactical discussion and training manuals show favoured tactics and weapons and assumptions on effectiveness, into which disinformation can be fed. Terror groups' own propaganda and recruitment messages can be used against them and to inoculate potential recruits. The structure of websites mimics the structure of organisations - Hezbollah's is very top-down with instructions for supporters whereas Al-Qaeda sites are very interactive and nonhierarchical (Shahar 2007).

\section{Surveillance, profiling and data sharing}

Alongside the development in communications technology that has driven the growth of the Internet, we continue to see exponential increases in computing capability and data storage capacity. Processing power has doubled roughly every two years, increasing a million-fold since 1965. Bandwidth and storage capacity are growing even faster, doubling every 12 months (Brown and Korff 2004:9-16). 
New surveillance technologies exploiting these capabilities include mechanisms to monitor, screen and analyse records of billions of telephone and e-mail communications; "bugs" and tracing technologies that can access the geographical position of mobile phones and act as a remote listening device; and hard-to-detect (even with anti-virus tools) "spyware," surreptitiously installed on a suspect's PC by the authorities, that can remotely and secretly monitor a suspect's online activities, passwords and e-mail, and even the PC's camera and microphone. Surveillance computers do not just surveil: they direct the attention of police and other authorities to "targets" identified by algorithm (Brown and Korff 2004).

There has been a commensurate expansion in "dataveillance": the monitoring of the "data trails" left by individuals in numerous transactions, through access to communications databases containing such trails. The EU's 2006 Data Retention Directive stipulates the mandatory retention, beyond the period for which they may be stored under "normal" data protection rules, of electronic communications data by providers of communications services. This data includes records of telephone numbers dialled and e-mail senders and recipients but not the content of calls or messages. The rules on access to communications data and on data retention are opaque and do not guarantee that data on innocent individuals will not be obtained and held by law enforcement authorities, or used in "profiling" (as discussed later). The picture of an individual that can be built up from communications data is immensely detailed. There is little room for privacy when state investigators can see with whom we communicate, what we read and watch online, and where we travel with mobile phones.

Data gathered by law enforcement agencies are now available to be shared across Europe under the principle of "availability," defined in the "Hague Programme" of the European Union as follows:

With effect from 1 January 2008 the exchange of ... information should be governed by conditions set out below with regard to the principle of availability, which means that, throughout the [European] Union, a law enforcement officer in one Member State who needs information in order to perform his duties can obtain this from another Member State and that the law enforcement agency in the other Member State which holds this information will make it available for the stated purpose, taking into account the requirement of ongoing investigations in that State.

The methods of exchange of information should make full use of new technology and must be adapted to each type of information, where appropriate, through reciprocal access to or interoperability of national databases, or direct (on-line) access (European Commission 2005)

This allows data sharing and free access without any of the usual "obstacles" contained in the traditional instruments for transnational cooperation between law enforcement agencies. These include the 1959 (Council of Europe) European Convention on Mutual Assistance in Criminal Matters and its two additional protocols and the EU Convention on Mutual Assistance in Criminal Matters of 2000 (which builds on the CoE Convention), with its additional protocol, which both came into effect in 2005. The procedures under these treaties take time and, more importantly, involve formal requests for specified information and often require judicial authorisation. ${ }^{1}$

\footnotetext{
${ }^{1}$ To see those requirements as "problems" and "obstacles" is to ignore that they constitute fundamental safeguards for the individual. As the European data protection authorities put it in their statement from a recent meeting: "In view of the increasing use of availability of information as a concept for improving the fight against serious crime and the use of this concept both on a national level and between Member States, the lack of a
} 
Law enforcement agencies in Europe now commonly rely on the use of "profiles" to target suspects. Such profiles are increasingly created not by any one national police force (and/or secret service), but as part of international (in particular intra-EU) co-operation. In order to "facilitate targeted searches for would-be terrorists" member states gather data from registers of residents, foreigners, university students and similar information sources. Their aim is to match such data against "physical, psychological or behavioural" characteristics that are thought by law enforcement agencies to indicate a high probability of terrorist activity (Privacy International 2005).

The police and secret services do not just search these massive data resources in order to find previously identified suspects of specific (terrorist or other) offences. Increasingly, they "trawl" through such databases in order to "match" all those in those databases against a predetermined (but dynamically updated) "profile." Moreover, such searches are commonly "intelligence-led" - based on secret, unchallengeable information; and carried out as part of European (rather than just national) policies. Profiles created in this manner suffer from builtin biases of which even software producers are often unaware, or that may only become apparent when these programs are used in practice - and in the latter case only if their operation is adequately monitored for such distortions (Brown and Korff 2004).

Many of these technologies pose inherent threats to privacy: they allow the State extremely close control over citizens' lives. But they are not infallible - on the contrary, these technologies are subject to serious, inherent limitations and biases. "Profiling" and "data mining" may seem to work up to a point, but they inevitably lead to actions against very large numbers of innocent people, on a scale that is both unacceptable in a democratic society and renders the "trawl" useless. Attempts to identify very rare incidents or targets from a very large data set are highly likely to result in unacceptably large numbers of "false positives" (identifying innocent people as suspects) or "false negatives" (not identifying real criminals or terrorists). This is referred to scientifically as the "base-rate fallacy"; colloquially, as: "if you are looking for a needle in a haystack, it doesn't help to throw more hay on the stack" (Schneier 2006). A recent US National Research Council report concluded: "there is not a consensus within the relevant scientific community nor on the committee regarding whether any behavioral surveillance or physiological monitoring techniques are ready for use at all in the counterterrorist context given the present state of the science" (2008).

\section{The changing role of the police}

In many European countries the police are increasingly seen as part of a wider "full societal alliance," implementing overall state policies. This inevitably increases the area in which the state feels justified to take action - including intrusive or punitive action - against people who have not (yet) committed any crime. In respect of offences such as narcotics possession and prostitution, this may not necessarily involve use of the criminal law. However in the area of terrorism the aim is to prevent possible crimes by people who may commit them. Law enforcement agencies have lobbied for powers to arrest and detain people who they think may be likely to commit crimes, or at least terrorist crimes (Cobler 1976). Indeed, preventive detention of such suspects is already a feature of the UK's Anti-Terrorism, Crime and Security Act 2001.

The definitions of the crimes in question - or of more general "grounds for suspicion" [Verdachtsmomente] that are felt to justify police action - are becoming increasingly vague.

harmonised and high level of data protection regime in the Union creates a situation in which the fundamental right of protection of personal data is not sufficiently guaranteed anymore" (Article 29 Working Party 2007). 
In spite of the great attention given by states to terrorism, especially after " $9 / 11$," even this concept is still largely undefined (Bowring 2006: 78). Specifically, neither the 1977 European Convention on the Suppression of Terrorism, nor the 1999 UN International Convention for the Suppression of Terrorist Bombings defines the word "terrorism." 2 Nor has the UN Security Council (or, for that matter, the EU) adopted a definition, in spite of the fact that it mandates punitive actions against suspected "terrorists." Lord Carlile, the UK's Independent Reviewer of Terrorism Legislation, concluded that: "There is no universally accepted definition of terrorism. It remains the subject of continuing debate in international bodies" (2007).

Apart from "terrorism", many states have now criminalised acting for "terrorist purposes", "supporting terrorism", "possession of materials that may be of use to terrorists" (irrespective of an intention to actually provide them to terrorists), "apologising for terrorism" and even "extremism" (Hirsch 2007). Punitive measures are increasingly envisaged against people perceived as "enemies of the State" or of "our democratic legal order" - even if their opinions and actions (although perhaps repulsive) would in the past not have been considered to constitute criminal offences. The "bringing forward" [Vorverlegung] of police action to such matters risks penalising people for their views and beliefs, rather than for actual acts against society.

The current focus on trying to prevent individuals (in particular, young Muslims) from being drawn into "extremism," linked to the fight against terrorism, fits into these wider developments. As with previous actions against individuals deemed to be suspicious because they belong to a specific group, or fit a certain stereotype, this is almost certain to lead to discrimination against such minority groups. ${ }^{3}$ The fact that a supposedly sophisticated computer-generated algorithm replaces a coarse stereotype does little to prevent this. By being incomprehensible even to those that rely on it, and effectively unchallengeable by those that are targeted, it aggravates the risk of discrimination.

A further major change in the policing environment concerns the relationship between the police and intelligence agencies. The former are working increasingly closely with, and relying on information obtained and passed on by, the latter. The police are also adopting many of the techniques and technologies of the intelligence agencies. As a result, the basis for police "interest" in a person, and the nature of the evidence against that person, are hidden. This has a direct impact on the treatment of such a person, who is likely to be spied upon, harassed, arrested, denied a job or a research post (Institute for Race Relations 2004) - all without knowing why, or able to challenge the reasons for such actions (or without even being aware of them). The ever-closer relationship between the police and intelligence agencies undermines the fairness of trials against persons accused of being involved in organised crime

\footnotetext{
${ }^{2}$ One of the problems with finding an acceptable definition is the difficult relationship between terrorism, "political offences" and liberation struggles. There is a tendency in various instruments to list certain offences and to then declare that they will constitute terrorism if they are carried out for broadly political motives. E.g., one could read a definition into the European Convention on the Suppression of Terrorism, if one were to say that terrorism covers the offences listed in Articles 1 and 2 of that Convention, when "inspired by political motives": in a way, the Convention tries to overcome certain restrictions on international co-operation in respect of "political" crimes by excluding the relevant offences from that definition, even if carried out for political reasons. Cf. also Article 3(1) of Framework Decision 2002/475/JHA. But there are also problems with defining terrorism purely by reference to such motives, or to certain types of offences. Note for instance that the 2005 CoE Convention includes the crime of "public provocation" of terrorism.

${ }^{3}$ E.g., through the use in the UK in the 1970 s and 80 s of so-called "sus laws," allowing stopping and searching of people on the mere (subjective) suspicion of individual police officers - powers which were used in a grossly discriminatory way before being finally repealed (but which are being brought back in new forms in recent antiterrorism laws).
} 
or terrorism, in that courts increasingly allow effectively secret evidence and evidence from anonymous witnesses to form the basis for a conviction (Vervaele 2005).

\section{Proportionality and the European legal framework}

European privacy law is complex, developing under a range of separate (Council of Europe, Single Market and Third Pillar EU) instruments, often ad hoc, by different national and international (European) judicial and other bodies.

Data protection has been developed on the basis of Article 8 of the European Convention on Human Rights (ECHR). Over the last decade the European Court of Human Rights has given strong recognition to data protection principles under this article, in particular in the cases of Peck v. the UK (concerning CCTV), Amann v. Switzerland (concerning telephone interception), Rotaru v. Romania (concerning secret service files) and Copland v. the UK (concerning the question of when the legal basis for processing of personal data can be considered to be adequate - to constitute "law" - in terms of the ECHR).

Data protection is however also increasingly seen as a sui generis right, in particular in the EU Charter of Fundamental Rights, in which it is given a separate provision (Article 8). More specifically, the following general European data protection instruments have been developed:

- The 1981 Council of Europe Convention for the Protection of Individuals with regard to Automatic Processing of Personal Data and its Additional Protocol;

- Directive 95/46/EC of the European Parliament and the Council of 24 October 1995 on the protection of individuals with regard to the processing of personal data and on the free movement of such data; and

- Directive 2002/58/EC of the European Parliament and of the Council of 12 July 2002 concerning the processing of personal data and the protection of privacy in the electronic communications sector (also referred to as the Directive on Privacy and Electronic Communications or DPEC).

Under these instruments, rules and guidelines have been issued that specifically relate to processing of personal data for law enforcement purposes. These include, in particular, $\mathrm{CoE}$ Recommendation $\mathrm{R}(87) 15$ of the Committee of Ministers to Member States, Regulating the Use of Personal Data in the Police Sector (1987). This recommendation has become the effective standard on the issue: it is expressly referred to in various European police cooperation instruments, including the Schengen and Europol treaties and associated regulations, and is also regularly invoked in recommendations by the Parliamentary Assembly of the Council of Europe and its Committee of Ministers, by the Working Party, and the European Parliament.

The European Court of Justice in Luxembourg has also been strict in its application of data protection principles (derived from both the ECHR as reflected in "general principles of Community law" and from the above EC directives); see in particular the cases of Österreichischer Rundfunk v. Austria and Lindqvist v. Sweden. It is clear from these cases that in the view of the European Court of Justice, data protection is a fundamental, constitutional issue that should be applied in accordance with the jurisprudence of the European Court of Human Rights. The ECJ has clearly endorsed, and adopted for itself, the typical, "standard" approach to human rights developed by the Strasbourg Court - and follows this approach also and in particular in its assessment of cases relating to the Framework Directive.

In their judgments the European Court of Human Rights and the European Court of Justice have developed a broad range of standards around data protection and law enforcement. They 
require a legal basis for any collection, storage, use, analysis, disclosure/sharing of personal data for law enforcement and anti-terrorist purposes - but a vague, broad general statutory basis is not sufficient. Such processing must be based on specific legal rules relating to the particular kind of processing operation in question. These rules must be binding, and they must lay down appropriate limits on the statutory powers such as a precise description of "the kind of information that may be recorded", "the categories of people against whom surveillance measures such as gathering and keeping information may be taken" and the circumstances in which such measures may be taken. Legislation must include a clearly set out procedure to be followed for the authorisation of such measures, limits on the storage of old information and on the time for which new information can be retained. It must also include explicit, detailed provision concerning the grounds on which files can be opened, the procedure to be followed for opening or accessing the files, the persons authorised to consult the files, the nature of the files and the use that may be made of the information in the files. Such rules can be set out in subsidiary rules or regulations - but in order to qualify as "law" in Convention terms, they must be published.

In order to properly comply with the core "purpose-specification and limitation" principle, it is not sufficient to specify that processing serves "the police task" or even a specific police task (investigation and prosecution of crime; countering immediate threats; more controversially, "prevention"). States must be as precise as possible. Personal data, collected for one specific police purpose (e.g. countering threats) can only be used for another specific purpose (e.g. investigating offences) if the data could have been independently collected for that second purpose. The police or other law enforcement agencies should never collect personal data "just in case."

The EC Data Protection Directive stipulates that if a person is subjected to a fully automated decision, the individual should (at least) have the right to know the logic involved in this decision, and measures should be taken to safeguard the individual's legitimate interests. The scope and application of this principle is still rather unclear, even in the First Pillar. However, the underlying principle - that it would violate "human identity", "dignity" or "personality" to treat anyone on that basis without stringent safeguards - must surely also be applied in the Third Pillar. This clearly has implications for the "profiling" of terrorist suspects.

In addition, there must be strong "safeguards established by law" that ensure "appropriate [and effective] supervision of the relevant services' activities." The judiciary should "normally" carry out this supervision. There should otherwise be particularly strong alternative supervisory mechanisms, such as close Parliamentary scrutiny. This requirement is part of the test of whether the legal rule in question has the appropriate quality. But the existence of such procedures is also essential in the assessment of compliance with Art. 13 ECHR (the right to an effective remedy before a national authority). The European Court of Human Rights has confirmed that a remedy should be available to anyone with an "arguable claim" of a violation of a Convention right: there is no need to show that an actual violation has occurred - which in the case of secret surveillance would put individuals in an impossible position.

It follows from the above that the collection of data on "contacts and associates" (i.e. on persons not suspected of involvement in a specific crime or of posing a threat), the collection of information through intrusive, secret means (telephone tapping and e-mail interception), and the use of "profiling" techniques, and indeed "preventive" policing generally, must be subject to a particularly strict "necessity" and "proportionality" test, and surrounded with particularly strong safeguards. "Hard" (factual) and "soft" (intelligence) data should be clearly distinguished, and data on different categories of data subjects (officially indicted 
persons, suspects, associates, incidental contacts, witnesses and victims, etc.) should be clearly distinguished. The nature of information and intelligence coming from private parties requires additional safeguards, inter alia in order to ensure the accuracy of this information since these are personal data that have been collected for commercial purposes in a commercial environment. Access should only be allowed on a case-by-case basis, for specified purposes and be under judicial control in the Member States.

\section{Conclusion}

States have a positive obligation to protect the life of their citizens (Osman $v$ United Kingdom). They are obliged to do all that could be reasonably expected of them to avoid a real and immediate risk to life of which they have or ought to have knowledge. In this sense, the right to security has long been "codified" as a human right in the jurisprudence of the European Court of Human Rights. This doctrine is equally applicable to life-threatening situations as a result of a terrorist threat. The preamble to the Guidelines on Human Rights and the Fight Against Terrorism that the Council of Europe's Committee of Ministers adopted on 11 July 2002 refers to "the imperative duty of the States to protect their populations against possible terrorist acts." The same consideration can be found in the Guidelines on the Protection of Victims of Terrorist Acts, adopted by the Committee of Ministers on 2 March 2005.

However, in Osman the Court also stressed "the need to ensure that the police exercise their powers to control and prevent crime in a manner which fully respects the due process and other guarantees which legitimately place restraints on the scope of their action to investigate crime and bring offenders to justice, including the guarantees contained in Article 5 and 8 of the Convention." States thus have the difficult job of balancing competing human rights interests. They must protect their population against terrorist threats whilst safeguarding the fundamental rights of individuals, including persons suspected or convicted of terrorist activities.

Anti-terrorist and related policies have given an immense impetus to pre-existing developments in law enforcement surveillance of communications. These measures are often adopted on a temporary, emergency basis - but once introduced, become permanent and are extended into the general law. It is decreasingly common for sunset clauses to be included in such legislation (Walker and Akdeniz 2003). These measures present a direct challenge to citizens' privacy rights as articulated in Osman.

Policing is being "brought forward" to target not just criminal, but also more generally deviant behaviour. In the context of the fight against terrorism, this means individuals are targeted for being suspected "extremists" or for being suspected of being "opposed to our constitutional legal order," even before committing any criminal (let alone terrorist) offence.

"Targets" of this kind are increasingly selected through computer "profiles." Selection is based upon algorithms that are effectively unchallengeable, but inevitably generate large numbers of "false positives" - innocent people being wrongly treated as suspected terrorists. Members of minority groups are more likely to be thus selected, leading to discrimination-bycomputer. Yet by being presented as "scientific," such discrimination is more difficult to challenge than previous, coarser stereotyping.

Even where "data mining" and "profiling" contributes to the apprehension of terrorists, there will always be a high proportion of "false negatives" - real terrorists that are not identified as such. We are giving up freedom without gaining security. In the process, all of us are increasingly placed under general, suspicion-less mass surveillance, with comprehensive data being captured on our activities. 
The European surveillance society is developing in a profoundly undemocratic way. Massive data collection and trawling threaten the most fundamental values supposedly underpinning the European political settlement, at both national and international level. In its actions against terrorism, the EU Council in particular is doing the European ideal a serious disservice by undermining democracy and the rule of law on the Continent.

At a more practical level these issues will create serious problems for European and wider international cooperation in the fight against terrorism, including constitutional challenges to such arrangements in countries in which data protection is given a high level of protection under the national constitution. They will therefore ultimately undermine, rather than help, in the fight against terrorism.

\section{References}

Article 29 Working Party (2007). Common position of the European Data Protection Authorities on the use of the concept of availability in law enforcement, adopted 11 May 2007. Available from http://www.edps.europa.eu/EDPSWEB/webdav/site/mySite/shared/Documents/Cooperation/Conferen ce_EU/07-05-11_Larnaca_availability_EN.pdf (last visited 27/2/08)

Bird, J. (2006). Terrorist Use of the Internet. The Second International Scientific Conference on Security and Countering Terrorism Issues, Moscow State University Institute for Information Security Issues

Brown, I. and Korff, D. (2004). Striking the Right Balance: Respecting the Privacy of Individuals and Protecting the Public from Crime. Wilmslow: Information Commissioner's Office

Brown, I. (2007). The law and economics of cybersecurity (Eds. Mark F. Grady and Francesco Parisi). Law Quarterly Review (123), 172-175

Bowring, W. (2006). The human rights implications of international listing mechanisms for 'terrorist' organisations. OSCE/ODIHR - UN HCHR Expert Workshop on Human Rights and International Cooperation in Counter-terrorism, ODIHR.GAL/14/07. Available from:

http://www.statewatch.org/terrorlists/OSCE-UN-feb-2007.pdf (last visited 25/2/08)

Carlile of Berriew (2007). The Definition of Terrorism. Cm 7052, London: The Stationary Office

Cobler, S. (1976). Die Gefahr geht von den Menschen aus: der vorverlegte Staatsschutz. Berlin: Rotbuch

Dutton, W.H. and Helsper, E. (2007). Oxford Internet Survey 2007 Report: The Internet in Britain. Oxford: Oxford Internet Institute

European Commission (2005). The Hague Programme: ten priorities for the next five years. The Partnership for European renewal in the field of Freedom, Security and Justice. COM(2005) 184 final

European Data Protection Supervisor (2007). Third opinion of the European Data Protection Supervisor on the Proposal for a Council Framework Decision on the protection of personal data processed in the framework of police and judicial co-operation in criminal matters, Official Journal of the European Union C 139/1

Ford, R. (2004). Beware rise of Big Brother state, warns data watchdog. The Times, 16 August 2004. Available from http://www.timesonline.co.uk/tol/news/uk/article470264.ece (last visited 28/2/08)

Institute for Race Relations (2004). Arrests under anti-terrorist legislation since 11 September 2001. Available at http://www.irr.org.uk/pdf/terror_arrests_study.pdf (last visited 27/2/08)

Labi, N. (2006). Jihad 2.0, Atlantic Monthly pp.102-107, July/August 2006. Privacy International (2005). Discrimination and Anti-Terror Policy Across Europe. Available from http://www.privacyinternational.org/article.shtml?cmd\%5B347\%5D=x-347-360509 (last visited $27 / 2 / 08)$ 
Ryan, J. (2007). Countering Militant Islamist Radicalisation on the Internet: A User Driven Strategy to Recover the Web. Dublin: Institute of European Affairs

Schjolberg, S. (2007). Terrorism in Cyberspace - Myth or reality? Available at http://www.cybercrimelaw.net/1-2007.html

Schneier, B. (2006). Data mining for terrorists. Schneier on Security, 9 March 2006. Available from http://www.schneier.com/blog/archives/2006/03/data_mining_for.html (last visited 25/2/08)

Shahar, Y. (2007). The Internet as a Tool for Counter-Terrorism. Patrolling and Controlling Cyberspace, Garmisch-Partenkirchen

Stenersen, A. (2007). Chem-bio cyber-class - Assessing jihadist chemical and biological weapons. Jane's Intelligence Review, 1 September 2007

US Army (2005). Army Regulation 530-1, Operations Security (OPSEC). 19 April 2007

US National Research Council (2008). Protecting Individual Privacy in the Struggle Against Terrorists: A Framework for Program Assessment. Washington DC: National Academies Press

Vervaele, J. (2005). Terrorism and information sharing between the intelligence and law enforcement communities in the US and the Netherlands: emergency criminal law? Utrecht Law Review, 1, 1

Walker, C. and Akdeniz, Y. (2003). Anti-Terrorism laws and data retention: war is over? Northern Ireland Legal Quarterly, 54, 2, 159-182 